\title{
9 Institutionalisation of Social Enterprise in Romania
}

Historical Milestones and SE Models Development

\author{
Mihaela Lambru and Claudia Petrescu
}

\section{Introduction}

Social-economy traditions in Romania are deeply connected with the main political, economic and social evolutions that have occurred within the country since 1990 . The present chapter aims to present the evolution and current situation of social enterprise (SE) in Romania. The first section analyses the historical background that has influenced the inception and development of social enterprises in the country. We then present the main stages that can be distinguished in the development of social enterprises in Romania, highlighting for each stage important legislative benchmarks. In the third section, we provide a presentation of the different SE models that we have identified. We conclude by analysing current trends and challenges in the Romanian SE field.

\section{Historical Background of Romanian Social Enterprises}

In Romania, the revival of the associative sector and the development of social-economy organisations, including social enterprises, were made possible by the systemic political changes that occurred after 1989 .

During the 1990s, market fundamentalism shaped the economic policies of the country and promoted a dichotomous state/market model, in which the state played an increasingly small part in public-service provision, and market exchanges favoured profit-driven economic activities (Stark and Bruszt 1998; Cerami 2006; Cerami and Vanhuysse 2009). This neoliberal model was mainstreamed throughout all former communist countries, leading to drastic decisions related to privatisation, public-service provision and welfare systems. Due to the privatisation and restructuring of the economic system, organisations depending on the communist agro-industrial system experienced a decline, while other types of organisation reconfigured their organisational status and business model. Cooperatives, which had hitherto been part of the mainstream economy, were relegated to the edges of the economic system, and their membership was drastically reduced; they became almost invisible 
as economic and social actors. Mutual associations became independent from the party/state and modernised their business model, and their jointly owned property (commons) was restored to them. But the organisations that experienced the most dramatic renaissance and further development after 1989, in both quantitative and qualitative terms, were associations and foundations-a development which in turn played an important role in promoting and shaping an enabling policy framework for social enterprises in Romania.

The development of a policy environment fostering the growth of social enterprises in the country has been strongly influenced by the structural changes that have taken place since the 1990s in two main strategic areas: social-policy reform and public-administration reform. Over the last decades, social-policy reform has followed the international trend towards the development of a "welfare mix". A marketisation of social services occurred in Romania, as in other countries, but with limited extent and a much-reduced policy toolkit compared with other Western countries. Elements of new public management (NPM) have been introduced across the Romanian public administration, but without a clear understanding of how the new theoretical background may affect the way in which public organisations operate. Elements of incomplete or limited decentralisation and regionalisation hindered the development of strong local/ regional actors promoting local-development strategies-in which social enterprises can be integrated. Without significant reforms to modernise public services and open the public market to various categories of contractors, it is difficult to create the right setting for SE development.

\section{Main Development Stages of Social Enterprises in Romania}

If we take a close look at the evolution of social enterprise in Romania, we can identify four main development stages.

\subsection{Rebirth of the Non-Profit Sector and Repositioning of Other Social-Economy Actors (1990-1998)}

In the early 1990s, as briefly sketched earlier, Romania witnessed a significant rebirth of non-profit organisations (associations, foundations and mutual-aid associations) and a collapse of the cooperative sector. The growth of the non-profit sector was both quantitative and qualitative.

The functioning of associations and foundations was regulated by Law 21/1924, which was rediscovered after the fall of the communist regime. Inspired by the French legislation from 1901, the Romanian law was permissive regarding the development, by non-profit organisations, of entrepreneurial/commercial activities with the aim of supporting the organisational mission. Social-entrepreneurship initiatives started to 


\section{Lambru \& Petrescu}

appear in the early 1990s; they were promoted mainly by associations and foundations, which looked for ways to gain more resources for their operations. These initiatives were small-scale operations, carried out in an environment that did not foster such entrepreneurial endeavours.

Within the complex family of non-profit organisations, a special case was represented by mutual associations. There are two types of mutualaid associations in Romania: those for retirees and those for employees (both created in order to fight the social and financial exclusion of their members), and the latter's development diverged from that of the rest of the non-profit sector. In the 1990s, indeed, contrasting with the overall rebirth of the non-profit sector, there was a decline in the number of units and membership of employees' mutual-aid associations, due to the closure of big economic units.

Romanian traditional cooperatives were notably absent from the debates and reforms regarding the social economy in general, and social enterprises in particular. In Romania, the communist regime (19481989) had brought about a massive change in all societal domains. Under communism, cooperatives' structure and functioning were influenced by communist ideology, which viewed cooperative property as a special type of collective property and a form of transition to state property. Cooperatives were part of the centralised and planned economic system; they were politically controlled and played a major role in reaching the socioeconomic objective of full employment targeted by the political regime. Worker cooperatives continued to exist after the fall of communism because, unlike agricultural cooperatives, their membership was not built up "by force" and, according to the law and in opposition to state-run enterprises, they were actually private businesses based on cooperative property. Still, their role in the economy was considerably reduced (Cace et al. 2010; Cruceru 2010; Crisan 2010; Lambru and Petrescu 2014). Cooperative enterprises, which were perceived as institutions belonging to the old system, were confronted with the need to find a new identity and to reform the cooperative system in order to meet market imperatives. In the years following the fall of communism, the cooperative sector also had to face major issues linked to property restitution to former owners, decreased production due to the lack of markets for certain products, governance issues, a significant drop in membership numbers and significant communication and public-image issues.

\subsection{The Partnership Stage: Paving the Way for SE Institutionalisation (1998-2006)}

The second period that can be distinguished in the development of social enterprise in Romania could be referred to as the "partnership stage". During this period, Romanian associations and foundations became more and more connected to the policy process through advocacy, 
public-participation activities and involvement in decision-making processes, at least at the formal level. Public consultation became a legal requirement for all governmental bodies as a result of a series of procedural reforms in policy making. Two very important laws for goodgovernance reform in Romania were also adopted during this period: Law 544/2001 on Free Access to Public Information and Law 52/2003 on Transparency of Decision in Public Administration. This stage was dominated by the issue of good governance and the process of integration into the European Union.

Public organisations (at both the central and local levels) as well as associations and foundations matured, allowing for the introduction of public/private-partnership practices and the development of welfare-mix systems. A benchmark for this development stage is the enactment of Law 34/1998 on Subsidies for Private Entities Providing Social Assistance Services. Law 34/1998 was followed by other new laws and government ordinances enabling public/private partnerships and social contracting in various policy areas. However, almost twenty years later, the toolkit used and the management capacity of public authorities remain limited.

Another benchmark was the enactment of the new legislative framework regulating the activity of associations and foundations, namely Government Ordinance (GO) 26/2000 (which replaced Law 21/1924). Expanding and modernising the conditions under which associations and foundations could perform an entrepreneurial activity were very high on the non-profit sector's agenda; under GO No. 26/2000, these organisations are allowed to carry out economic activities, provided these activities are auxiliary in nature; separate accounting records should also be kept. Applicable legislation does not provide for fiscal incentives or exemptions for associations and foundations, unless their businessgenerated income is under $€ 15,000 /$ year. Any organisation that exceeds this threshold has to pay the same taxes as any SME-without, however, being entitled to the advantages granted to SMEs (access to loans, to various specific funding opportunities, etc.). That is why entrepreneurial associations and foundations that want to carry out an entrepreneurial activity usually prefer to set up a business in which they are the majority shareholder.

At that stage, in Romania, we could talk about the existence of a consolidated associative sector with an active presence in various policy areas. Given the withdrawal of development technical-assistance programmes and of a majority of public and private international donors from Romania because of the country's upcoming accession to the European Union, the concerns of the associative sector about an imminent funding crisis were increasing. Public-policy schemes to support public/private partnerships in social services through domestic sources had only recently been introduced, with a limited budget; corporate-social-responsibility practices were in an early stage; and the possibilities to collect funds from 


\section{Lambru \& Petrescu}

individuals were poorly regulated by law and therefore hard to implement. Under these circumstances, the adoption of the so-called " $2 \%$ Law" (Law 571/2003, in its article 57, introduces the possibility for individuals to allocate an amount representing up to $2 \%$ of their annual income tax to support to NPOs' activity) was of particular interest for the development of associations and foundations and generated positive effects in terms of ensuring a direct link between citizens and these organisations.

In this specific context, associations and foundations became gradually increasingly interested in the development of a new policy framework enabling entrepreneurial activities. Romania's accession to the EU paved the way for a new policy narrative regarding social inclusion through work-integration social enterprises, and for a favourable economicpolicy context for social entrepreneurship. Associations and foundations became the strongest advocate for the institutionalisation of social enterprises in Romania.

At the same time, mutual-aid associations continued their development. After the fall of communism, mutual-aid associations were no longer coordinated by state institutions; they regained their legal independence, while maintaining their name and partially their membership structure (their membership could also include other members from the communities, not only retirees or employees). Nevertheless, it was only after the year 2000 that they started to implement major changes in their activities and in the services they provided to their members. Studies conducted in Romania at the time in the field of social economy (Lambru 2013a; Petrescu 2013a; Cace et al. 2010; Barna 2014; Lambru and Petrescu 2016) revealed that mutual-aid associations achieved the greatest entrepreneurial success of all social-economy entities.

\subsection{The Institutionalisation Stage (2007-2015)}

The third stage, which corresponds to the period of institutionalisation of social enterprises in Romania, started in 2007, at the time of the country's accession to the EU. We can say that Romanian social enterprises were then at the beginning of the institutionalisation process. This specific phase was characterised not only by a quantitative growth of the third sector in terms of number of associations and foundations and of number of employees; increased diversity of entrepreneurial projects; and improved visibility of social enterprises through research and advocacy actions-but also still by limited public support, lack of recognition and absence of an enabling policy framework for social enterprises.

Interest in the European approach to promoting the social-economy concept and social enterprise as a specific type of organisation also gained ground in Romania during this period. After 2010, strongly influenced by the European social-inclusion agenda and under pressure from 
the associative sector, the government set up public consultations on SE legislation. The associative sector and other social and economic actors played a major role in advocating for SE legislation and were deeply involved in shaping the SE law.

In the stage of institutionalisation, a good understanding, on the part of decision-makers and practitioners alike, of the conceptual framework behind the reality of social enterprises is crucial. Concurrently with the increasing interest, on the part of public authorities, to promote and support initiatives aiming at SE development, the interest in related research also grew, and debates about the specificity of this type of organisation, its social utility, its characteristics and the profile of relevant organisational actors intensified. In Romania, the concept of social enterprise was introduced at the same time as the notion of social economy gained renewed interest, and this created confusion among decision-makers, the leaders of "old and new social-economy" organisations and de facto social enterprises in search of visibility and legitimacy. Both the concept of social economy and that of social enterprise were poorly understood and, as a result, any attempt to design a good legal framework to foster SE development was problematic. The EMES approach to the concept, with its indicators of the ideal-typical social enterprise, was then disseminated through research and training and debated with various stakeholders (Lambru and Petrescu 2012; Lambru 2013b).

Following the path of other countries in the region and at the European level, in 2011, a draft law on the social economy was submitted for public consultation by the Romanian Ministry of Labour, Family and Social Protection. The main public-consultation events of the SE institutionalisation process were supported through the Sectoral Operational Programme for Human Resources Development (SOP HRD) 2007-2013, financed by the European Social Fund and featuring the Key Area of Intervention 6.1 and Axis 6.2, which aimed at increasing social inclusion through improved access to and participation in the labour market for vulnerable groups. The draft law was vividly debated during the following years; the process involved many stakeholders through different forms of consultation.

\subsection{Building Up a Future for Social Enterprises (Since 2015)}

In Romania, the legal recognition of social enterprise took place within the larger context of designing a general legislative framework for the social economy. Law 219/2015 on the Social Economy was adopted in 2015; it regulates social enterprises, defined as organisations that fulfil specific criteria-priority given to social aims over the maximisation of profit, solidarity and collective responsibility, democratic governance, allocation of at least $90 \%$ of the profit to the pursuit of the social aim and the constitution of a statutory reserve. The law also lists the types of organisations 


\section{Lambru \& Petrescu}

(cooperatives, credit cooperatives, associations, foundations, mutual-aid associations and other entities that fulfil the social-economy principles) that can be recognised as social enterprises, provided they meet the specific criteria included in the law. The law not only creates a legal framework for all existing social enterprises (which were already regulated through pre-existing legal forms), but it also regulates a specific form of workintegration social enterprise (another category of WISE, beside sheltered workshops, which focus exclusively on the work integration of people with disabilities) which was hitherto not recognised by law, namely that of "social-insertion social enterprise". Social-insertion social enterprises aim to combat the exclusion, discrimination and unemployment of disadvantaged persons through their socio-professional integration. The recognition of social enterprises is achieved, according to the law, through a certification process: certification as social enterprise (art. 9) and registration in the National Register of Social Enterprises (art. 26-27). For social-integration social enterprises, the law also includes a social label (art. 13-15).

Because of the degree of bureaucratisation of the certification process and due to the fact that the fiscal and financial rewards attached to it are limited, de facto social enterprises show only limited interest in officially registering as such: by August 2019, only 114 social enterprises had been registered in the National Register of Social Enterprises, of which 12 were work-integration social enterprises.

Another landmark event during this stage, beside the adoption of Law $219 / 2015$, was the reform of procurement legislation. Thereby translating EU procurement rules (2014/24/EU) in Romanian legislation, Law 98/2016 and Law 99/2016 were enacted in 2016. The new legislation offers interesting perspectives to social enterprises aiming to develop general-interest services. Special provisions regarding social clauses and reserved contracts have been introduced, but the implementation remains limited so far.

The development of specific legislation for social enterprises was mainly related to the "Europeanisation" pressure-the existence of an EU policy framework for social enterprise, with related budgets, generates an isomorphic effect in Central and Eastern Europe (CEE). In Romania and, more broadly, in the CEE region, social enterprises are considered by decision-makers to be mainly a public-policy tool, useful for the development of jobs for disadvantaged categories. The policy narrative emphasises almost exclusively the social-inclusion aspects.

\section{Identification of SE Models}

In Romania, the majority of SE initiatives are launched by associations and foundations, which frequently set up business entities under their own control with a view to running economic activities. Applicable legislation for non-profits prescribes that they may set up business entities 
where they are the majority shareholder provided that any dividends thus obtained are not reinvested in the business entity but are used to achieve the goal of the association or foundation.

Statistical data are missing, but qualitative analysis and case studies indicate that most of the Romanian social enterprises are small-sized (Petrescu 2013b, 2013c; Lambru 2013b).

Our research on SE models in Romania, inspired by the EMES approach and EU definition, identified four main types of social enterprise: entrepreneurial non-profit organisations (associations and foundations), mutual-aid associations (mainly retirees' mutual-aid associations), work-integration social enterprises (including two models: sheltered workshops and social-insertion social enterprises), and cooperatives pursuing general-interest goals.

\subsection{Entrepreneurial Non-Profit Organisations (Associations and Foundations)}

Associations and foundations carrying out an entrepreneurial activity are the most dynamic actors in the Romanian social-economy sector. They were the main advocates of the institutionalisation of the social economy and the main beneficiaries of ESF funding stimulating the creation of new social enterprises. Associations and foundations are regulated by Government Ordinance 26/2000 (completed by Law 246/2005). Three major sub-groups can be distinguished among entrepreneurial NPOs, depending on their main beneficiaries: general-interest organisations (which constitute the largest group), community-interest organisations and mutualinterest organisations (pursuing their own members' interest).

While, in the 1990s, the Romanian non-profit sector had a relatively small size (Salamon et al. 1999, 2000), in the period 2000-2015, the number of associations and foundations was nearly multiplied by four and the number of their employees, almost by five. Data from the National Institute of Statistics indicate that, in 2015, there were 42,707 active associations and foundations in the country, employing 99,774 persons (see Table 9.1). But this overall quantitative growth of the nonprofit sector at the national level hides geographical disparities: indeed, associations and foundations' territorial dispersion is uneven, with a concentration in urban areas (where approximately $75 \%$ of organisations are located) and in the more developed regions of Romania (55\% of associations and foundations are located in the three most developed regions of the country's eight regions) (FDSC 2017). Due to this uneven geographical distribution, the level of service accessibility is uneven across the country; it is particularly low in the areas faced with the most serious social issues-namely rural and poor areas.

In the last 30 years, an important challenge for associations and foundations has been linked to the issue of securing the financial resources necessary for their activity (Lambru and Vamesu 2010; FDSC 2016). In the resource 


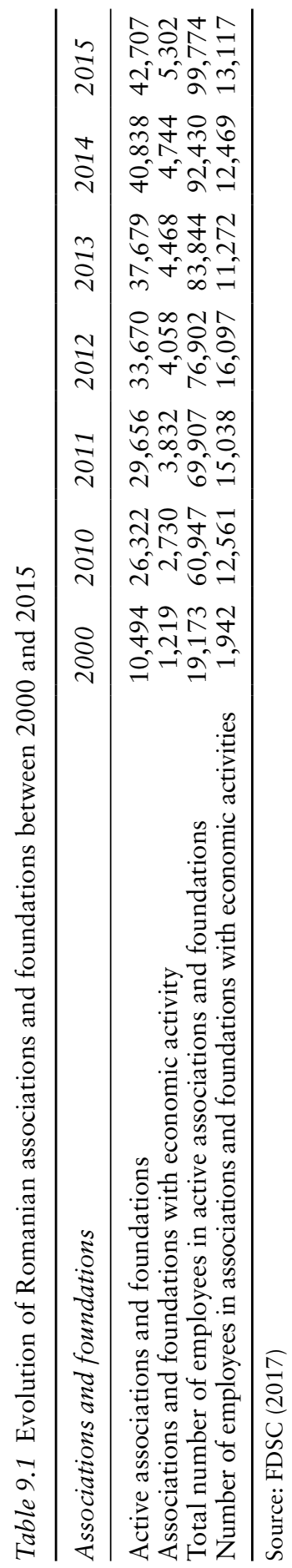


mix of most of the associations and foundations, the major source of funding is grants, followed by sponsorship and donations and, to a lesser extent, contracts with public authorities (FDSC 2017). Another possibility to secure financial resources, apart from the traditional methods (grants, sponsorship, subsidies, donations, membership fees, etc.), is the development of associations and foundations' economic activity, which enables them to independently secure part of their resources in order to be able to fulfil their social goals. As a result of the measures implemented to encourage associations and foundations to carry out economic activities, the number of entrepreneurial NPOs has increased in the last fifteen years, reaching 5,302 organisations in 2015 (which represents $12 \%$ of active associations and foundations), while the number of employees in these organisations rose to 13,117 (13\% of the total number of employees in associations and foundations).

Social enterprises set up by associations and foundations pursue predominantly social goals, namely reaching out to the community or to specific disadvantaged population groups. With a view to achieving their social goals, these associations and foundations engage in different economic activities, depending on their members' skills and knowledge, and they create various types of social enterprise, such as producer, agricultural or marketing cooperatives, sheltered workshops (work-integration social enterprises), socio-medical units, service-provision businesses (body care, repair shops, tourism, etc.) or farmers' associations.

\subsection{Mutual-Aid Associations}

In Romania, the majority of mutual-aid associations are employees' mutual-aid associations (EMAAs) and retirees' mutual-aid associations (RMAAs). Each of these two types is covered by specific legislation (Law 122/1996 for EMAAs and Law 540/2002 for RMAAs), which provides the legal framework for the operations of these organisations and describes the types of activities that they can carry out. These organisations have survived the communist period and reinvented themselves and developed after 1990; they appear to respond to a clear need of citizens to cope with risks of financial exclusion.

RMAAs were set up to address seniors' needs-mostly not only financial needs but also social, medical and other kinds of needs. They are registered as associations according to Government Ordinance 26/2000. In the mid-1990s, RMAAs reorganised their operations, diversified their services, increased their membership; these organisations represent today one of the most successful types of bottom-up social enterprise in the country (Lambru and Petrescu 2016). Older people's access to financial services (such as loans) used to be a major problem because of their "unbankability" (commercial banks do not grant them loans due to their low income and to their age). According to the law, the main activity of an RMAA is the provision of refundable loans under advantageous conditions to seniors who are members of the organisation or who belong to 


\section{Lambru \& Petrescu}

the community within which it operates. Because of the lack of development of social services for the elderly and of the low incomes of elderly people, RMAAs also carry out other types of complementary activities for their members, such as organising cultural or leisure activities, or providing services using members' labour, funeral services, health services, etc. All those services are set up in order to meet the members' need at a price below the market price. In the past few years, RMAAs have set up social services for the elderly which they deliver at no cost to their members, and some services which they provide in exchange for a small payment to non-members. All the services provided are funded by the interest revenue generated by the lending activity, membership fees and the sale of services to members and the community.

During the 2000-2015 period, Romania witnessed a significant increase in the number of RMAAs and of these organisations' employees, which both almost doubled; and even though a significant decrease can be observed in the number of EMAAs, the number of their employees increased slightly. Data from the National Institute of Statistics indicate that, in 2015, there were in Romania 2,412 active EMAAs, employing 3,498 persons, and 219 RMAAs, employing 2,450 persons (see Table 9.2).

\subsection{Work-Integration Social Enterprises (sheltered Workshops and Social-Insertion Social Enterprises)}

WISEs represent an active labour-market instrument, aiming to integrate disadvantaged people in the labour market. In Romania, as already mentioned, there are two forms of WISE: sheltered workshops, which exclusively target people with disabilities (Constantinescu 2013), and social-insertion social enterprises, which aim to integrate vulnerable people (including people with disabilities) in the labour market.

\section{Sheltered Workshops}

Sheltered workshops are a work-integration instrument for people with disabilities. The first initiatives of this kind were established in the first years of the post-communist period. Sheltered workshops can be developed by companies, associations, foundations or public administration and, according to Law 448/2006 on the Protection of People with Disabilities, at least $30 \%$ of their employees should be people with disabilities. Like in other European countries, sheltered workshops are considered in Romania to be an occupational solution and an intermediate stage on the path towards employment on the mainstream labour market for people with more severe disabilities. Unfortunately, there are no official data regarding the transition of people with disabilities from sheltered workshops to the mainstream labour market, but different analyses show that the share of workers who achieve such transition is generally very 
Social Enterprises in Romania 163

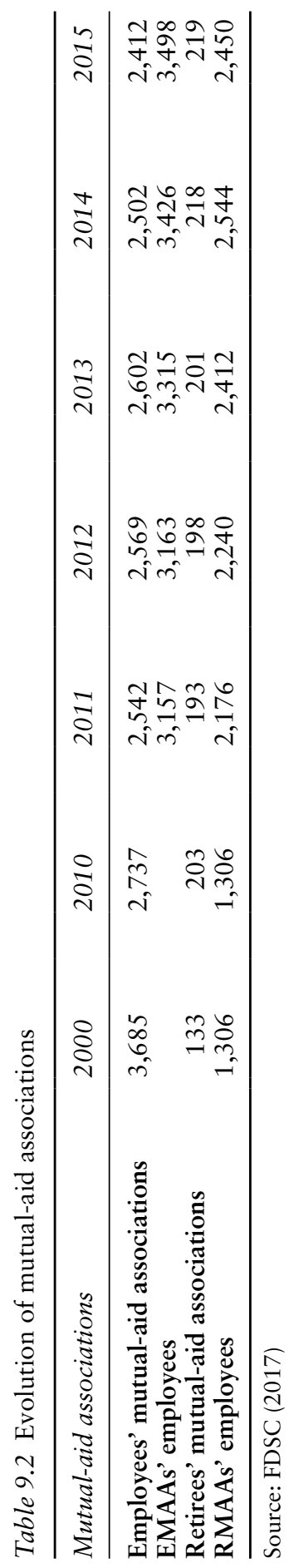




\section{Lambru \& Petrescu}

low (Romanian Academic Society and Motivation Foundation Romania 2010; Achitei et al. 2014; Alexiu et al. 2014).

Like other European countries (such as Austria, Denmark, France, Italy, Poland or Spain), Romania has a quota system to encourage employers to hire people with disabilities. The legislation (Law 448/2006) requires that, in private or public institutions with at least 50 employees, at least $4 \%$ of the staff be people with disabilities. Any employer who does not meet this requirement has to pay to the state, each month, an amount equal to $100 \%$ of the national minimum salary for every position that should be occupied by a person with a disability.

Until 2017, as an alternative mentioned in Law 448/2006, the defaulting company could also buy goods or services, for the same amount, from recognised sheltered workshops. This provision substantially contributed to the development of sheltered workshops through the creation of a special market for their products/services. Such special market was particularly important for sheltered workshop; indeed, due to the fact that at least $30 \%$ of their employees should be people with disabilities, their production costs are higher than those of mainstream enterprises, and they cannot be competitive on the market. In 2006, there were 48 sheltered workshops in Romania; following the introduction, in 2006, of the provision that created a specific market for their sales, the number of sheltered workshops increased significantly; by the end of 2007, there were 150 sheltered workshops in the country. This growth continued in the following years: there were 481 sheltered workshops in 2010; 564 in 2012; 667 in 2013; 759 in 2016; and 708 in 2017 (ANPD 2017; Achitei et al. 2014; Ministry of Labour, Family and Social Protection 2010).

Since 2017, the requirements have changed (Government Ordinance 60/2017), and the only option for the defaulting company is now the payment to the state. This has led to a dramatic decrease in the activity of sheltered workshops, as the market for their products has been substantially reduced.

Most of the sheltered workshops are managed by companies (68\%) or associations and foundations (22\%); those managed by cooperatives only represent a small share $(3 \%)$ of the total. The number of sheltered workshops managed by associations and foundations was multiplied almost by four over a six-year period, from 56 in 2011 to 197 in 2017 (see Table 9.3).

Of all the persons with disabilities employed in 2016, 6\% worked in sheltered workshops; this share might appear relatively small, but it should be noted that the people employed by sheltered workshops are often persons with severe disabilities. A decrease in the number of employees with disabilities in sheltered workshops has been recorded lately; at the end of 2017, this number had decreased by 465 persons (from 2,015 in 2016 to 1,550 at the end of 2017), due to the application of the provisions of Government Ordinance 60/2017 and the abolition of the possibility offered to economic agents that did not comply with legal requirements in terms of employment of disabled workers to buy goods/services produced by sheltered workshops instead of paying a fine to the state. 
Table 9.3 Evolution of Romanian sheltered workshops between 2008 and 2017

\begin{tabular}{lrrrrrrrr}
\hline & 2008 & 2010 & 2011 & 2012 & 2013 & 2016 & 2017 \\
\hline Sheltered workshops & 207 & 481 & 330 & 564 & 667 & 759 & 708 \\
$\quad$ Managed by: & & & & & & & \\
$\quad$ Limited-liability companies & 156 & 378 & 245 & 391 & 455 & 495 & 452 \\
$\quad$ Associations and foundations & 24 & 58 & 56 & 109 & 149 & 204 & 197 \\
Cooperatives & 22 & 24 & 11 & 20 & 19 & 16 & 15 \\
$\quad$ Other types of private & 5 & 21 & 18 & 40 & 43 & 43 & 42 \\
$\quad$ organisations & 0 & 0 & 0 & 4 & 1 & 1 & 2 \\
$\quad$ Public institutions & & & & & & \\
\hline
\end{tabular}

Source: ANPD (2017); Achitei at al. (2014)

\section{Social-Insertion Social Enterprises}

Social-insertion social enterprises constitute a new form of social enterprise, which was created by Framework Law 219/2015 on the Social Economy. Social-insertion social enterprises focus on the social integration of vulnerable groups. In order to make Law 219/2015 fully operational, from 2016 onwards, specific secondary legislation was developed. Furthermore, public-procurement reform (Law 98/2016) introduced specific benefits for social-insertion social enterprises.

Framework Law 219/2015 defines this new form of WISE and specifies that social-insertion social enterprises are to be certified through a social label and should meet some specific criteria, in addition to those imposed on social enterprises: at least $30 \%$ of employees must belong to vulnerable groups; the cumulated work time of these employees must represent at least $30 \%$ of the total work time of all employees; and the enterprise must aim to combat exclusion, discrimination and unemployment of disadvantaged people through their socio-professional integration.

\subsection{Cooperatives Pursuing General-Interest Goals}

There are four types of cooperative in Romania: worker cooperatives, consumer cooperatives, credit cooperatives and agricultural cooperatives. These traditional cooperatives are strongly engaged in economic activities; the economic aim is the most important of their goals. The entire cooperative law is built exclusively around the needs and interests of cooperatives' members, and these organisations' activities are carried out for their members and with their members. Even though cooperatives are run democratically and respect the "one person, one vote" principle in the general assembly, regardless of each member's contribution to the capital, they do not have a multi-stakeholder governance, and only their members are involved in the decision-making process. On the basis of these various elements, we consider that Romanian "old-type" cooperatives should not be considered as social enterprises. 


\section{Lambru \& Petrescu}

In the last years, though, a new generation of cooperatives has been emerging and developing in Romania, most of which display the characteristics of social enterprises. This "re-discovery" of the cooperative sector still suffers the impacts of the communist period; cooperatives nowadays have to deal with psychological barriers linked to the past forced "cooperativisation" in rural areas, and with a negative perception of all cooperatives in the general public. Most of the new cooperatives are established as a result of specific policy measures (in rural areas, cooperatives obtain a better score than agricultural limited-liability companies or individual landowners when they submit a request for funding, and they are entitled to more incentives from public authorities than individual farmers or agricultural limited-liability companies) and to support provided by European funds. Among these new cooperatives, those that do not only aim to promote the interests of their members but also, more broadly, pursue general-interest goals can be considered as social enterprises. Many of them have developed economic activities in areas, such as the environment, culture, fair trade, and rural and sustainable development. Between 2007 and 2016, 82 cooperatives were created thanks to European funds dedicated to the development of the social economy in Romania. Some cooperatives (most of them agricultural cooperatives) were also created thanks to the support provided by private funds.

\section{Conclusion}

The emergence of social enterprise in Romania can be seen mainly as a bottom-up phenomenon. Indeed, the major and most successful social enterprises in the country are grassroots initiatives, set up to respond to the urgent needs of citizens.

This bottom-up dynamic is combined with the isomorphic pressure exerted by the EU and which has resulted in a type of legislation on social enterprise that focuses almost exclusively on work-integration social enterprises and in the development of externally driven initiatives, stimulated by the existence of generous funding for work-integration projects for disadvantaged groups.

Reflecting on the current trends and challenges in the Romanian SE sector, we can identify several issues.

We can first observe a growing demand for general-interest services. The Romanian social-services sector currently remains underdeveloped and underfunded, but the demand for social services that better respond to identified social needs is growing fast. Particularly, striking in this regard is the case of services for the elderly. The Romanian "baby boomers" will retire in 10-15 years from now (in 2030-2035). This is the largest demographic group in Romanian society, and a lot of pressure for the modernisation of social services can be expected. Social enterprises such as RMAAs are already involved in providing services for the elderly, and they can offer an interesting business model, effectively complementing governmental action. 
An important challenge for Romanian social enterprises lies in the limited awareness and understanding of the SE concept. Indeed, the lack of awareness and poor understanding of the identity and social utility of social enterprises by decision-makers and the general public, despite these organisations' legal recognition, represent a barrier for their development and jeopardise their scaling-up process. The term "social" is usually associated with the activities carried out by charities or with the work integration of vulnerable groups, not with entrepreneurship. SE success stories are hardly known and understood by public administration and the general public. Also, in the current ideological climate, which is unfavourable to civil-society organisations in general, it is necessary for all types of social enterprise to increase their capacity to educate and mobilise members and clients, to better explain the principles underlying their very functioning, and to stress out their specificity.

Finally, public support for SE development remains limited, and this also represents an important challenge for Romanian social enterprises. EU funding played a very important role in boosting the legislative reform and in supporting a new type of social enterprise, focusing on the work integration of disadvantaged groups. This type of funding encouraged not only the development of many valuable SE initiatives but also a lot of opportunistic behaviours. But beside the support for work-integration social enterprises, public resources to support bottom-up active social enterprises are very scarce, the entrepreneurial activities of associations and foundations are not encouraged or supported by public authorities, and mutual-aid organisations are poorly understood by and almost invisible to policymakers. In this context, a better use of the opportunities generated by new public-procurement legislation appears necessary.

\section{References}

Achitei, A., Munteanu, M., Marian, R., Iftimoaiei, M. \& Drelea, A. (2014) Dezvoltarea economiei sociale prin unitati protejate autorizate, Iasi: Alaturi de Voi Foundation.

Alexiu, T. M., Bîrneanu, A. G., Baciu, E. L., Sandvin, J. T., Fyling, I., Breimo Paulsen, J., Lazăr, T. A., Dincă, M. \& Ungureanu, R. (2014) The Labour Market Integration of People with Disabilities in Europe and Romania. Literature and Policy Review Report. Available HTTP: www.e-qual-see.ro/?page_id=130 (accessed on February 10, 2018).

ANPD (2017) Raport de activitate cu privire la unitățile protejate autorizate în perioada 03.05.2007-31.12.2017 aferent anului 2017, Bucharest: Autoritatea Nationala pentru Persoanele cu Dizabilitati. Available HTTP: http://anpd.gov. ro/web/informatii-utile/unitati-protejate-autorizate/rapoarte-de-activitate/.

Barna, C. (2014) Social Economy Atlas, Bucharest: FDSC.

Cace, S., Arpinte, D. \& Scoican, N. A. (eds) (2010) Social Economy in Romania, Bucharest: Expert.

Cerami, A. (2006) Social Policy in Central and Eastern Europe. The Emergence of a New European Welfare Regime, Munster, Hamburg, Berlin, Vienna and London: LIT Verlag. 


\section{Lambru \& Petrescu}

Cerami, A. \& Vanhuysse, P. (2009) Post-Communist Welfare Pathways. Theorizing Social Policy Transformation in Central and Eastern Europe, Basingstoke: Palgrave Macmillan.

Constantinescu, S. (2013) Economia sociala si ocuparea fortei de munca. Integrarea grupurilor vulnerabile pe piata muncii, Bucharest: Social Economy Institute.

Crisan, I. (2010) Cooperația de consum. Evoluție, structuri, strategii de dezvoltare, Bucharest: University Publishing House.

Cruceru, D. (2010) Istoria şi doctrina cooperatistă în România, Bucharest: Artifex. FDSC (2016) Indexul Sustenabilitatii Organizatiilor Societatii Civile 2015Romania. Bucharest: Fundatia pentru Dezvoltarea Societatii Civile (FDSC). Available HTTP: www.fdsc.ro/library/files/indexusaidromania_2015+.pdf.

FDSC (2017) Romania 2017. Sectorul Neguvernamental: Profil, Tendinte, Provocari, Bucharest: Fundatia pentru Dezvoltarea Societatii Civile (FDSC). Available HTTP: www.fdsc.ro/library/files/romania-2017.pdf.

Lambru, M. (2013a) Casele de ajutor reciproc, Iasi: Polirom.

Lambru, M. (2013b) Intreprinderile sociale, Iasi: Polirom.

Lambru, M. \& Petrescu, C. (2012) "Trends and challenges for social enterprises in Romania", International Review of Social Research, Vol. 2, No. 2, pp. 163-83.

Lambru, M. \& Petrescu, C. (2014) "Surviving the crisis: Worker cooperatives in Romania”, Organization, Vol. 21, No. 5, pp. 730-45.

Lambru, M. \& Petrescu, C. (2016) “Bottom-up social enterprises in Romania. Case study-retirees' mutual aid association", International Review of Sociology, Vol. 26, No. 2, pp. 247-61.

Lambru, M. \& Vamesu, A. (eds) (2010) Romania 2010. Nongovernmental Sector-Profile, Tendencies, Challenges, Bucharest: Litera.

Ministry of Labour, Family and Social Protection (2010) Raport de cercetare privind economia socială în România din perspectivă europeană comparată. Available HTTP: www.mmuncii.ro/pub/imagemanager/images/file/RapoarteStudii/301210Raport\%20de\%20cercetare_ES\%20anexe.pdf.

Petrescu, C. (ed) (2013a) Economia sociala in contextul dezvoltarii locale, Iasi: Polirom.

Petrescu, C. (ed) (2013b) Cooperativele in Romania: Actori ai dezvoltarii socioeconomice, Iasi: Polirom.

Petrescu, C. (ed) (2013c) Organizațiile colective ale proprietarilor de terenuri agricole şi forestiere, Iasi: Polirom.

Romanian Academic Society and Motivation Foundation Romania (2010) Accesul la piata muncii redus pentru persoanele cu dizabilitati, Buzau: Alpha MDN.

Salamon, L., Anheier, H., List, R., Toepler, S., Sokolowski, S. \& Associates (1999) Global Civil Society. Dimensions of the Nonprofit Sector, Baltimore, MD: The Johns Hopkins Center for Civil Society Studies.

Salamon, L., Sokolowski, S. W. \& Anheier, H. K. (2000) "Social origins of civil society: An overview", Working Paper of the Johns Hopkins Comparative Nonprofit Sector Project, No. 38, Baltimore: The Johns Hopkins Center for Civil Society Studies.

Stark, D. \& Bruszt, L. (1998) Postsocialist Pathways. Transforming Politics and Property in East Central Europe, Cambridge: Cambridge University Press. 